\title{
Direct effects of ovine follicular fluid on ovarian steroid secretion and expression of markers of cellular differentiation in sheep
}

\author{
B. K. Campbell ${ }^{1 \dagger}$, H. Engelhardt ${ }^{1 \ddagger}$, A. S. McNeilly ${ }^{2}$, L. M. Harkness ${ }^{1}$, \\ M. Fukuoka ${ }^{1 \S}$ and D. T. Baird ${ }^{1 *}$ \\ ${ }^{1}$ Department of Obstetrics and Gynaecology, University of Edinburgh; and ${ }^{2} M R C$ Unit of Reproductive Biology, \\ Centre for Reproductive Biology, 37 Chalmers Street, Edinburgh, EH3 9EW, UK
}

\begin{abstract}
The objective of this study was to assess the effect of ovine follicular fluid (FF) treatment (with or without FSH replacement) during the late follicular phase on plasma concentrations of gonadotrophins and the development of the ovulatory follicle. Ovarian steroid secretion and expression of mRNA encoding inhibin $\alpha$ and $\beta_{A^{\prime}} \beta_{B}$ subunits, P450 aromatase and P450 17 $\alpha$-hydroxylase were used as endpoints. After induction of luteolysis by injection of $100 \mu \mathrm{g}$ cloprostenol on days 10-12, Scottish Blackface ewes were allocated to one of three groups: (1) control $(n=7)$ : no further treatment; (2) FF ( $n=9)$ : subcutaneous injections of $3 \mathrm{ml}$ steroid-free ovine follicular fluid at $9 \mathrm{~h}$ intervals, 18 and $27 \mathrm{~h}$ after cloprostenol injection; (3) FF $+\mathrm{FSH}(n=8)$ : injections of follicular fluid as above plus subcutaneous injections of 0.36 iu ovine FSH at $6 \mathrm{~h}$ intervals, 18,24, and $30 \mathrm{~h}$ after cloprostenol injection. Jugular venous blood samples were obtained via indwelling cannulae at $6 \mathrm{~h}$ intervals from 0 to $36 \mathrm{~h}$ after cloprostenol injection, and at $10 \mathrm{~min}$ intervals from 12 to $18 \mathrm{~h}$ (control phase) and from 30 to $36 \mathrm{~h}$ after cloprostenol injection (treatment phase). At laparotomy, $36 \mathrm{~h}$ after cloprostenol injection, ovarian venous blood was collected and ovaries were removed and processed for in situ hybridization. Plasma concentrations of FSH, luteinizing hormone (LH) and oestradiol were determined by radioimmunoassay. Follicular fluid treatment resulted in a decrease $(P<0.001)$ in $\mathrm{FSH}$ concentrations associated with an acute decrease in ovarian steroid secretion $(P<0.01)$ and a specific depression in $P 450$ aromatase, $(P<0.001)$, inhibin-activin $\beta_{\mathrm{B}}$ subunit $(P<0.05)$ and thecal $\mathrm{LH}$ receptor $(P<0.001)$ expression. Follicular fluid treatment had no effect on inhibin-activin $\alpha$ and $\beta_{\mathrm{A}^{\prime}}$ subunit or P450 17 $\alpha$-hydroxylase expression. FSH co-treatment with follicular fluid restored circulating FSH concentrations to normal values and reversed some of the effects of follicular fluid (androstenedione, testosterone and progesterone secretion, and inhibin $\beta_{\mathrm{B}}$ and thecal LH receptor expression) but not oestradiol secretion or P450 aromatase expression. It was concluded that the actions of follicular fluid are mediated via both central effects on pituitary FSH secretion and by direct ovarian effects on granulosa cell aromatase activity. The results indicate that follicular fluid contains a factor that inhibits aromatase activity of granulosa cells directly and may play a role in the selection of the dominant follicle.
\end{abstract}

\section{Introduction}

In sheep, the number of ovulatory follicles and, hence, the ovulation rate, is rigorously controlled, with most breeds having a characteristic ovulation rate between one and three

\section{*Correspondence.}

'Present address: School of Human Development, NURTURE, Queens Medical Centre, University of Nottingham, Nottingham NG7 2UH, UK.

tPresent address: Department of Animal and Poultry Science, University of Guelph, ON N1G 2W1, Canada.

spresent address: Department of Gynaecology and Obstetrics, Faculty of Medicine, Kyoto University, Sakyoku, Kyoto 606, Japan.

Revised manuscript received 15 April 1999.
(Scaramuzzi et al., 1993). The use of real-time ultrasonography to study the pattern of follicle development in sheep throughout the oestrous cycle has revealed that large ovulatory sized, or dominant, follicle development occurs throughout the luteal phase as a series of 4-6 day periodic waves, with the number of follicles per wave being similar to the ovulation rate of that breed (Ginther et al., 1995; Souza et al., 1997a). Furthermore, these studies have shown that ovulatory follicles can be either derived from the large follicles present in the ovary at the time of luteal regression or recruited from the small antral follicle pool during the first $12-24 \mathrm{~h}$ of the follicular phase depending on the stage of the follicular wave at the time of luteolysis (Souza et al., 1997b). 


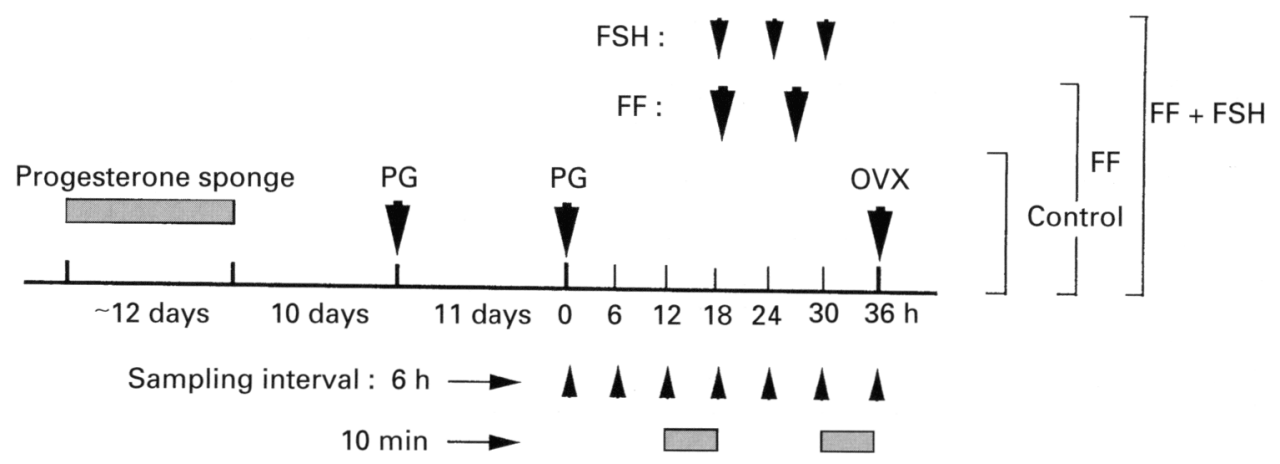

Fig. 1. Schematic representation of experimental design and sampling frequency. PG: injection of 100 $\mu \mathrm{g}$ cloprostenol; FF: subcutaneous injections of $3 \mathrm{ml}$ steroid-free ovine follicular fluid; FSH: subcutaneous injections of 0.36 iu ovine $\mathrm{FSH}$; OVX: ovariectomy.

However, understanding of the mechanisms that control these cycles of follicular recruitment, selection and dominance are incomplete.

It has been hypothesized that fluctuations in peripheral FSH concentrations, in response to variations in the degree of negative feedback provided by oestradiol and inhibin secretion, represent the mechanism of follicular recruitment and dominance (Baird, 1983) and much data have been accumulated to support this hypothesis. In both cattle (Adams et al., 1992; Gong et al., 1993) and sheep (Ginther et al., 1995; Souza et al., 1997a), there is compelling evidence that the emergence of a new follicular wave is associated with a transient increase in FSH, and that periods of follicular dominance are associated with basal FSH concentrations. Furthermore, studies using experimental models in which GnRH analogues have been used to suppress endogenous gonadotrophins with subsequent hormone replacement have shown that FSH alone can stimulate the recruitment and development of ovulatory sized follicles (Picton et al., 1990; Gong et al., 1996; Campbell et al., 1998), that dominant follicles are critically dependent on FSH support (Campbell et al., 1999) and that dominant follicles can transfer their gonadotrophic requirement from FSH to LH if it is delivered in low amplitude, high frequency pulses (Campbell et al., 1999).

While evidence for the FSH-threshold hypothesis of follicular dominance is compelling, an alternative hypothesis proposes that a dominant follicle actively secretes a factor or factors that directly suppress the development of subordinate follicles. Treating ewes with steroid-free follicular fluid late in the follicular phase, for more than $24 \mathrm{~h}$ after the induction of luteolysis, results in a delay in the onset of oestrus (McNeilly, 1984, 1985; Henderson et al., 1986, 1988). Further studies into this phenomenon in ewes with an ovarian autotransplant showed that follicular fluid treatment was associated with a rapid decrease in ovarian hormone secretion (Baird et al., 1990; Campbell et al., 1991a) that results from acute induction of atresia of the ovulatory follicles (Campbell et al., 1991a). However, as steroid-free follicular fluid treatment is associated with a decrease in FSH (McNeilly, 1984, 1985; Wallace et al, 1985; Wallace and McNeilly, 1985; Baird et al., 1990), owing to its inhibin content
(Leversha et al, 1987), these inhibitory effects of follicular fluid can be satisfactorily explained by the FSH-threshold hypothesis.

More compelling evidence for the dominant factor hypothesis comes from the demonstration that inhibin-free follicular fluid can delay oestrus (Law et al., 1992; Baxter et al., 1995), suppress ovarian steroid secretion (Campbell et al., 1991a) and induce follicular atresia (Campbell et al., 1991a; Law et al., 1992) without inducing significant changes in peripheral FSH concentrations. Furthermore, it has been demonstrated that direct ovarian infusion of follicular fluid can suppress ovarian function without any change in FSH (Campbell et al., 1996a) and that fractions of follicular fluid can inhibit FSH-dependent differentiation of granulosa cells in vitro (Baxter et al., 1995). The aim of the present study was to investigate this activity by assessing the effect of follicular fluid treatment, with or without FSH replacement, on ovarian steroid secretion and expression of mRNA encoding cytochrome $\mathrm{P} 450$ aromatase ( $\mathrm{P} 450_{\text {arom }}$ ), cytochrome $\mathrm{P} 45017 \alpha-$ hydroxylase $\left(\mathrm{P}^{4} 50_{17 \alpha}\right)$, inhibin-activin $\alpha, \beta_{\mathrm{A}}$ and $\beta_{\mathrm{B}}$ subunits and LH receptor, which were used as key markers of follicular differentiation.

\section{Materials and Methods}

\section{Animals}

Experiments were conducted in accordance with the Animal (Scientific Procedures) Act of 1986 (UK). During the breeding season (October-January), the oestrous cycles of 24 mature Scottish Blackface ewes (ovulation rate $1.3 \pm 0.1$ ) were synchronized by insertion of intravaginal progestagen sponges (Dunlop, Dumfries) for 12-14 days followed by injection of $100 \mu \mathrm{g}$ prostaglandin $\mathrm{F}_{2 \alpha}$ analogue, cloprostenol (Estrumate, Dunlop) 10 days after sponge removal.

\section{Experimental design}

A summary of the experimental design is provided (Fig. 1). All animals received a second injection of cloprostenol 
Table 1. Details of ${ }^{35}$ S-labelled riboprobe templates used for in situ hybridization

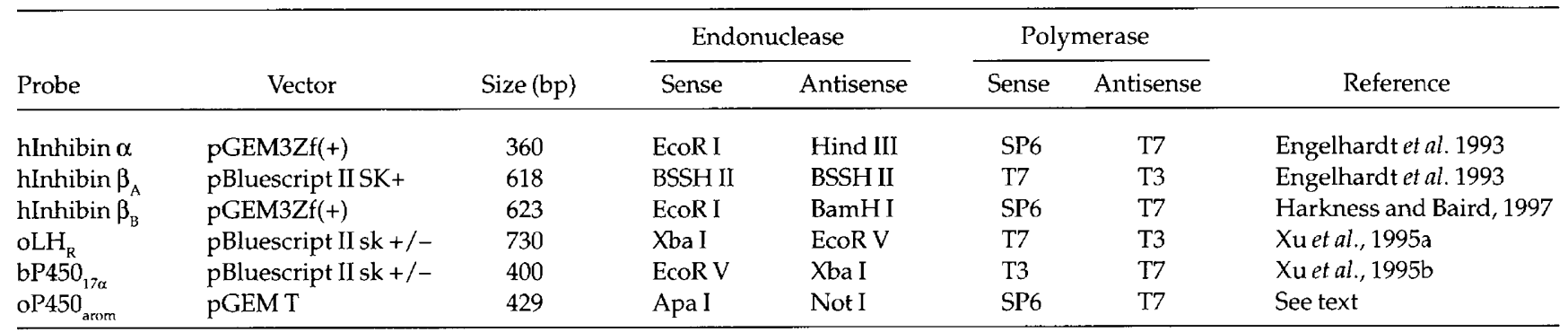

to induce the follicular phase for the experimental cycle, 11 days after the first (time $=0 \mathrm{~h}$ ). Jugular venous blood samples were obtained via indwelling cannulae at $6 \mathrm{~h}$ intervals from 0 to $36 \mathrm{~h}$ after cloprostenol injection, and at $10 \mathrm{~min}$ intervals $12-18 \mathrm{~h}$ and $30-36 \mathrm{~h}$ after cloprostenol injection. Treatments were assigned as follows: (1) control $(n$ =7): no further treatment; (2) FF ( $n=9)$ : subcutaneous injections of $3 \mathrm{ml}$ steroid-free ovine follicular fluid at $9 \mathrm{~h}$ intervals, 18 and $27 \mathrm{~h}$ after cloprostenol injection; (3) FF + FSH $(n=8)$ : injections of follicular fluid as above plus subcutaneous injections of 0.36 iu ovine FSH at $6 \mathrm{~h}$ intervals, 18,24 , and $30 \mathrm{~h}$ after cloprostenol injection. The amounts and timing of FSH were designed to restore the concentrations of FSH to those found in control ewes.

At $36 \mathrm{~h}$ after the second injection of cloprostenol, timed samples of ovarian venous blood were collected and ovaries were removed as described by Campbell et al. (1991b) and Engelhardt et al. (1993). The time chosen to collect ovaries was based on previous studies of the time course of hormone changes after injection of follicular fluid and corresponded to the nadir in secretion of oestradiol and androstenedione before ovulation or collapse of the follicle (Baird et al., 1990; Campbell et al., 1991a). Briefly, midventral laparotomies were performed under general anaesthesia, reproductive tracts were exteriorized and ovarian veins were cannulated. A timed $10 \mathrm{ml}$ sample of ovarian blood was collected from the left and right ovarian veins by gentle suction with a syringe. Both ovaries of each animal were then removed, the presence of large follicles $(>4 \mathrm{~mm})$ noted and ovaries were fixed overnight in freshly prepared $4 \%(\mathrm{v} / \mathrm{v})$ paraformaldehyde in PBS, pH 7.4 (PFA).

After fixation, ovaries were cut longitudinally in two or four slices, care being taken to cut through the largest follicles on each ovary. The tissue was then dehydrated by passage through a graded series of alcohols and embedded in paraffin wax. Serial sections (5 $\mathrm{mm}$ thickness) were mounted on slides coated with 3-aminopropyltriethoxysilane (TESPA; Sigma, St. Louis, MO), incubated overnight at $50^{\circ} \mathrm{C}$, and then processed for in situ hybridization as described by Harkness and Baird (1997).

\section{Preparation of follicular fluid and FSH}

Collection and preparation of the ovine follicular fluid used in these experiments have been described by Baird et al.
(1990). Briefly, follicular fluid collected from abattoir-derived ovaries was charcoal-stripped and passed through a C18 Sep-Pak cartridge to remove steroids, filter-sterilized and frozen until use. The follicular fluid contained $3235 \mu \mathrm{g}$ inhibin $\mathrm{ml}^{-1}$ ( $\mathrm{p} 1-26 \mathrm{a}$ ) and had a bioactivity of $8076 \mathrm{U} \mathrm{ml}^{-1}$ (Tsonis et al, 1986). The treatment regimen ( $3 \mathrm{ml}$ follicular fluid at $9 \mathrm{~h}$ intervals) was intended to reduce $\mathrm{FSH}$ to approximately $50 \%$ of control concentrations.

The experiment was performed in two trials, 2 months apart. In the first trial $(n=15)$, the FSH used was NIAMDDoFSH-14 (biopotency $=9 \times \mathrm{NIH}-\mathrm{FSH}-\mathrm{S} 1$ ) whereas, for the second trial $(n=9)$, USDA-oFSH-19-SIAFP (biopotency $=$ $94 \times$ NIH-FSH-S1) was used. For both trials, the appropriate amount of FSH was dissolved in sterile $0.9 \%$ saline containing $1 \%$ normal sheep serum before injection. The amount of FSH infused was chosen to maintain the FSH concentration at the amount found before the injection of prostaglandin, that is, during the luteal phase of the cycle.

\section{Radioimmunoassays}

Plasma concentrations of FSH, LH, and oestradiol were determined by previously established radioimmunoassays (McNeilly and Fraser, 1987; McNeilly et al, 1989; Campbell et al., 1990). The sensitivities of the assays for FSH, LH and oestradiol were $0.3 \mu \mathrm{g} \mathrm{l}^{-1}$ (USDA-oFSH-SIAFP-RP2), $0.2 \mu \mathrm{g} \mathrm{l}^{-1}$ (NIH-LH-S18) and $120 \mathrm{pg} \mathrm{l}^{-1}$ respectively. The intra- and interassay coefficients of variation of the assays used were $<15 \%$ in the ED20-80 range.

The total rate of ovarian steroid secretion was calculated by multiplying oestradiol concentrations in ovarian venous plasma by ovarian plasma flow rate (ovarian blood flow per minute corrected for haematocrit) for each ovary and summing these values for the left and right ovaries (Collett et al., 1973).

\section{Template generation and $c R N A$ probe synthesis}

Details of the cDNA templates and cRNA probe synthesis are presented (Table 1). With the exception of the $\mathrm{P} 450_{\text {arom }}$ cDNA templates, the preparation of these templates has been described elsewhere (see Table 1). For $\mathrm{P} 450_{\text {arom' }}$ a 429 base pair (bp) cDNA encoding ovine $\mathrm{P}^{4} 50_{\text {arom }}$ was generated by reverse transcriptase-polymerase chain reaction using ovine 
preovulatory follicle RNA and primers corresponding to highly conserved sequences present in the nucleotide sequence of bovine P450 (Genbank accession number U18447). The ovine P450 arom cDNA (corresponding to nucleotides 1406-1834 of the bovine P450 arom $)$ was subsequently ligated into the pGEM T vector (Promega UK Ltd, Southampton) and sequenced to verify identity. The ovine $\mathrm{P} 450_{\text {arom }}$ cDNA was $95 \%$ identical to the reported sequence of bovine $\mathrm{P} 4500_{\mathrm{arom}} \cdot{ }^{35} \mathrm{~S}$-labelled sense and antisense riboprobes were generated from their CDNA templates using methods described by Harkness and Baird (1997).

\section{In situ hybridization}

All in situ hybridization procedures were performed as described by Harkness and Baird (1997). Sections were deparaffinized twice in Histoclear (National Diagnostics, Atlanta, GA), rehydrated through a graded series of ethanols and post-fixed in $4 \%(\mathrm{v} / \mathrm{v})$ PFA. The sections were washed and digested with proteinase $\mathrm{K},\left(20 \mu \mathrm{g} \mathrm{ml}^{-1}\right.$; Sigma $)$ in a 100 mmol Tris $~^{-1}-10 \mathrm{mmol}_{\text {EDTA }} \mathrm{l}^{-1}$ buffer. Sections were washed and refixed in $4 \%(\mathrm{v} / \mathrm{v})$ PFA, washed twice in $0.25 \%$ acetic anhydride in $0.1 \mathrm{~mol}$ triethanolamine hydrochloride $\mathrm{l}^{-1}$ and washed again in PBS and saline, dehydrated through a graded series of ethanols $(50,70,85,95$ and $100 \%)$ and air dried.

The labelled probes were diluted to a concentration of $5 \times 10^{5}$ c.p.m. per slide, with a hybridization buffer $(62.5 \%$ deionised formamide; $25 \%$ of a $50 \%$ dextran sulphate solution; $7.5 \% 5$ mol NaCl ${ }^{-1} ; 1 \% 1$ mol Tris $l^{-1}, \mathrm{pH} 8.0 ; 0.2 \%$

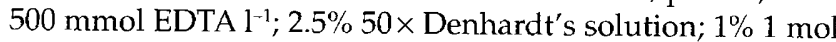
dithiothreitol $1^{-1}$ and $0.3 \%$ ultrapure water) heated to a temperature of $80^{\circ} \mathrm{C}$ for $2 \mathrm{~min}$ and cooled on ice before application to sections at $10 \mathrm{ml}$ per slide. Sections were overlaid with coverslips made from Gel Bond (FMC Bioproducts, Rockland, ME) and the slides were incubated overnight in a humidified chamber saturated with $2.5 \times$ standard sodium citrate and $50 \%$ formamide at $55^{\circ} \mathrm{C}$. After hybridization, the sections were washed in $5 \times \mathrm{SSC}$ with 0.01 mol dithiothreitol $1^{-1}$ at $55^{\circ} \mathrm{C}$, in $2 \times$ SSC with $50 \%$ deionized formamide and $0.1 \mathrm{~mol}$ dithiothreitol $\mathrm{l}^{-1}$ at $65^{\circ} \mathrm{C}$ and then

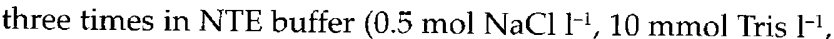
5 mmol EDTA $\left.1^{-1}, \mathrm{pH} 7.5\right)$ at $37^{\circ} \mathrm{C}$.

Sections were then treated with ribonuclease type III A (Sigma, $40 \mathrm{mg} \mathrm{ml}^{-1}$ in NTE) at $37^{\circ} \mathrm{C}$, then re-washed in NTE. The wash in $2 \times \mathrm{SSC}$ with $50 \%$ formamide and $0.1 \mathrm{~mol}$ dithiothreitol $\mathrm{l}^{-1}$ at $65^{\circ} \mathrm{C}$ was repeated. Sections were then washed in buffers containing decreasing amounts of salt solutions at room temperature $(2 \times$ and $0.1 \times$ SSC) and then dehydrated through a graded series of ethanols (50 and $85 \%$ containing $0.3 \mathrm{~mol} \mathrm{NH}_{4}$ acetate $1^{-1} ; 100 \%$ twice) and left to air dry.

Autoradiographic dipping in liquid emulsion was performed in a dark room with a safety light. Sections were dipped in Kodak NBT-2 (Rochester NY) and exposed for $1-5$ weeks at $4^{\circ} \mathrm{C}$, developed in Kodak D-19 developer at $15^{\circ} \mathrm{C}$, and fixed in Kodafix at room temperature. Slides were counterstained with haematoxylin (BDH, Glasgow) dehydrated and mounted in Pertex mounting media (CellPath, Hemel Hempstead).
Slides were examined under dark field using an Olympus microscope attached to a video camera and computer. The concentration of silver grains was measured using two different programmes. The silver grains of the riboprobes of inhibin $\alpha, \beta_{\mathrm{A}}$ and $\beta_{\mathrm{B}^{\prime}}$ aromatase and $\mathrm{LH}$ receptor were measured at $10^{6} \mathrm{~cm}^{-3}$, using an image analysis programme, Olympus PC-Task Manager Version 1.20A, Cue 2 Image Analysis Morphometry. The measurements of the silver grain density for the $17 \alpha$-hydroxylase were generated using Image-Pro Plus (Microsoft Windows 95) at $10^{6} \mathrm{~cm}^{-2}$. These results were then converted to $10^{6} \mathrm{~cm}^{-3}$.

Five fields per section were analysed with a coefficient of variation of $<15 \%$. One section per follicle was analysed for each probe and all sections were included in a single run for each probe. Sense probes were used in parallel with antisense probes on alternate sections to control for nonspecific hybridization. No signal was observed with sense probes in any tissue (data not shown). Sheep ovaries from untreated adult sheep during the luteal phase were included in each run as positive controls.

\section{Statistical analysis}

Because ovaries were not serially sectioned, follicles in a section were considered a sample of those in that particular ovary. Follicle diameters were measured to the nearest $0.5 \mathrm{~mm}$ using an eyepiece graticule, and then grouped into four size categories: $1-2 \mathrm{~mm}, 2-3 \mathrm{~mm}, 3-4 \mathrm{~mm}$ and $>4 \mathrm{~mm}$. In the case of the larger follicles, the diameter was measured in the section in which it was largest. Treatment effects on follicle number were tested using one way analysis of variance after $V^{\prime}(x+0.5)$ transformation.

Comparison of plasma gonadotrophin concentrations during $10 \mathrm{~min}$ sampling periods, steroid secretion rates and values for mRNA expression were made using one way analysis of variance on log-transformed data, whereas repeated measures analysis of variance was used to assess changes in gonadotrophin concentrations over time $(6 \mathrm{~h}$ samples). When initial $F$ tests were significant $(P<0.05)$, Duncan's multiple range procedure was used to compare individual means. LH pulse characteristics (frequency and amplitude) were determined using the Munro pulse analysis programme (Elsevier, Biosoft, Haddington, East Lothian) and compared using one way analysis of variance as described above. Hormone concentrations are presented as untransformed means \pm SEM, whereas $m R N A$ expression is presented as log grains $\mathrm{cm}^{-3}$.

\section{Results}

\section{FSH and LH concentrations in peripheral blood}

Before treatment with follicular fluid, there were no intergroup differences in plasma FSH concentrations in the $6 \mathrm{~h}$ samples (data not shown) or in samples collected over the initial period of intensive blood sampling, from $12-18 \mathrm{~h}$ after cloprostenol injection (Fig. 2). Follicular fluid treatment caused a $36 \%$ reduction in plasma FSH concentrations 
(a)
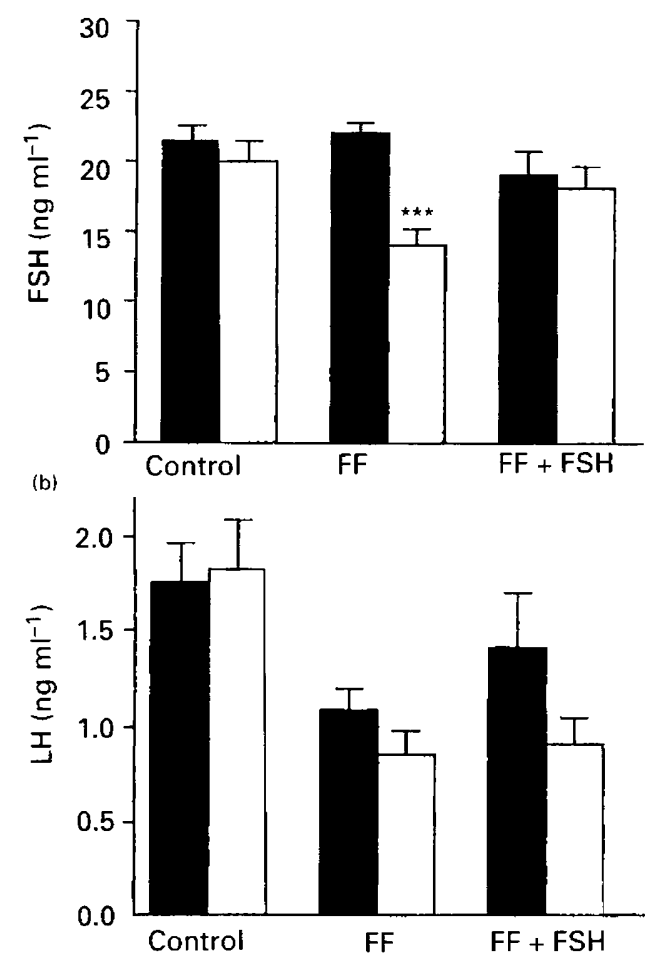

Fig. 2. Mean \pm SEM concentrations of (a) FSH and (b) LH before 12-18 h after cloprostenol injection; control phase) and after ( $\square$; $30-36 \mathrm{~h}$ after cloprostenol injection; treatment phase) treatment. ${ }^{* * *} P<0.001$ for comparison between control and treatment phases within a treatment group. FF: follicular fluid.

$(P<0.0001)$, which was reversed by concomitant treatment with FSH (Fig. 2).

Mean LH concentrations over the initial period of intensive blood sampling were lower $(P<0.001)$ in the FF group, before follicular fluid treatment. However, neither follicular fluid nor follicular fluid plus FSH treatment had any significant effect on mean LH concentrations (Fig. 2), interpulse interval $(1.9 \pm 0.7,2.3 \pm 0.6,3.8 \pm 0.9 \mathrm{~h}$ for control, FF and FF + FSH groups, respectively) or pulse amplitude $\left(1.7 \pm 0.3,0.9 \pm 0.2,1.2 \pm 0.5 \mu \mathrm{g} \mathrm{l}^{-1}\right.$ for control, FF and FF + FSH groups, respectively) over the treatment period, $30-36 \mathrm{~h}$ after cloprostenol injection

\section{Size distribution of follicles}

The size distribution of follicles exhibited the expected pattern (Turnbull et al., 1977) with a rapid decrease in the number of follicles as follicle size increased (data not shown). There were no differences in the number of follicles among the three treatment groups, except that there were more large $(>4 \mathrm{~mm})$ follicles in the FF + FSH group $(2.13 \pm 0.30)$ than in the control or FF groups $(1.29 \pm 0.18$ and $1.33 \pm 0.17$, respectively; $P<0.05$ ).

\section{Ovarian effects: secretion of ovarian steroids}

As reported by Campbell et al. (1991a) and Mann et al. (1992), ovarian steroid secretion from ovaries containing no large follicles was minimal and, as a result, only steroid secretion from ovaries containing at least one large (>4 mm) follicle has been presented (Fig. 3). When compared with untreated controls, treatment with follicular fluid resulted in a decrease $(P<0.05)$ in ovarian oestradiol, androstenedione, testosterone and progesterone secretion. Combined treatment with follicular fluid and FSH was largely able to prevent this depressive effect of follicular fluid on ovarian androstenedione, testosterone and progesterone secretion, but oestradiol secretion remained below $(P<0.05)$ control values.

\section{Ovarian effects: $m R N A$ expression for differentiative markers}

Expression of mRNA encoding $\mathrm{P} 40_{\text {arom }}$ was only detected in the granulosa cells of large follicles (Fig. 4). Treatment with follicular fluid caused a marked decrease $(P<0.001)$ in $\mathrm{P} 450_{\text {arom }}$ expression and combined treatment with follicular fluid and FSH was unable to reverse this effect (Fig. 4). In contrast, $\mathrm{P} 450_{17 \alpha}$ was expressed in the thecal cells of all follicles (Fig. 4), although the expression was greater $(P<0.01)$ in large than in small follicles $(4.8 \pm 0.6$ versus $2.8 \pm 0.3 \log$ grains $\mathrm{cm}^{-3}$, respectively). Neither follicular fluid nor follicular fluid plus FSH treatment had any effect on the expression of $\mathrm{P}_{450_{17 \alpha}}$ in large (Fig. 4) or small follicles (data not shown).

Inhibin-activin $\alpha, \beta_{\mathrm{A}}$ and $\beta_{\mathrm{B}}$ subunits were expressed exclusively in the granulosa cells (Fig. 5). Expression of inhibin $\alpha$ was greater in large than in small follicles $(5.5 \pm 0.7$ versus $3.4 \pm 0.3 \log$ grains $\mathrm{cm}^{-3} ; \mathrm{P}<0.01$ ) but was unaffected by follicular fluid and follicular fluid plus FSH treatment (Fig. 4). Similarly, expression of inhibin $\beta_{\mathrm{A}}$ was greater in large than in small follicles $(5.4 \pm 0.5$ versus $0.6 \pm 0.2 \log$ grains $\mathrm{cm}^{3} ; P<0.001$ ) and was unaffected by follicular fluid and follicular fluid plus FSH treatment (Fig. 4). Inhibin-activin $\beta_{\mathrm{B}}$ subunit expression was also confined mainly to large follicles (large versus small: $1.3 \pm 0.4$ versus $0.3 \pm 0.2 \log$ grains $\mathrm{cm}^{-3} ; P<0.05$ ) but was decreased $(P<0.05)$ by treatment with follicular fluid, and this effect was reversed by treatment with follicular fluid plus FSH (Fig. 5).

LH receptor was expressed in the thecal cells of all follicles, with follicular size having no effect on the amount of expression $\left(6.2 \pm 1.0\right.$ versus $4.4 \pm 0.5 \mathrm{log}$ grains $\mathrm{cm}^{-3}$ in large and small follicles from controls, respectively). In both large (Fig. 5; $P<0.001)$ and small $\left(1.8 \pm 0.4 \log\right.$ grains $\mathrm{cm}^{-3}$; $P<0.01)$ follicles, treatment with follicular fluid decreased thecal LH receptor expression, and this effect was largely prevented by treatment with follicular fluid plus FSH in both large (Fig. $4 ; P=0.3)$ and small follicles $(2.5 \pm 0.5 \log$ grains $\left.\mathrm{cm}^{-3} ; P=0.09\right)$ when compared with controls. LH receptor was only intensely expressed in the granulosa cells in a small number of large antral follicles, and so these data were not analysed for treatment effects. 

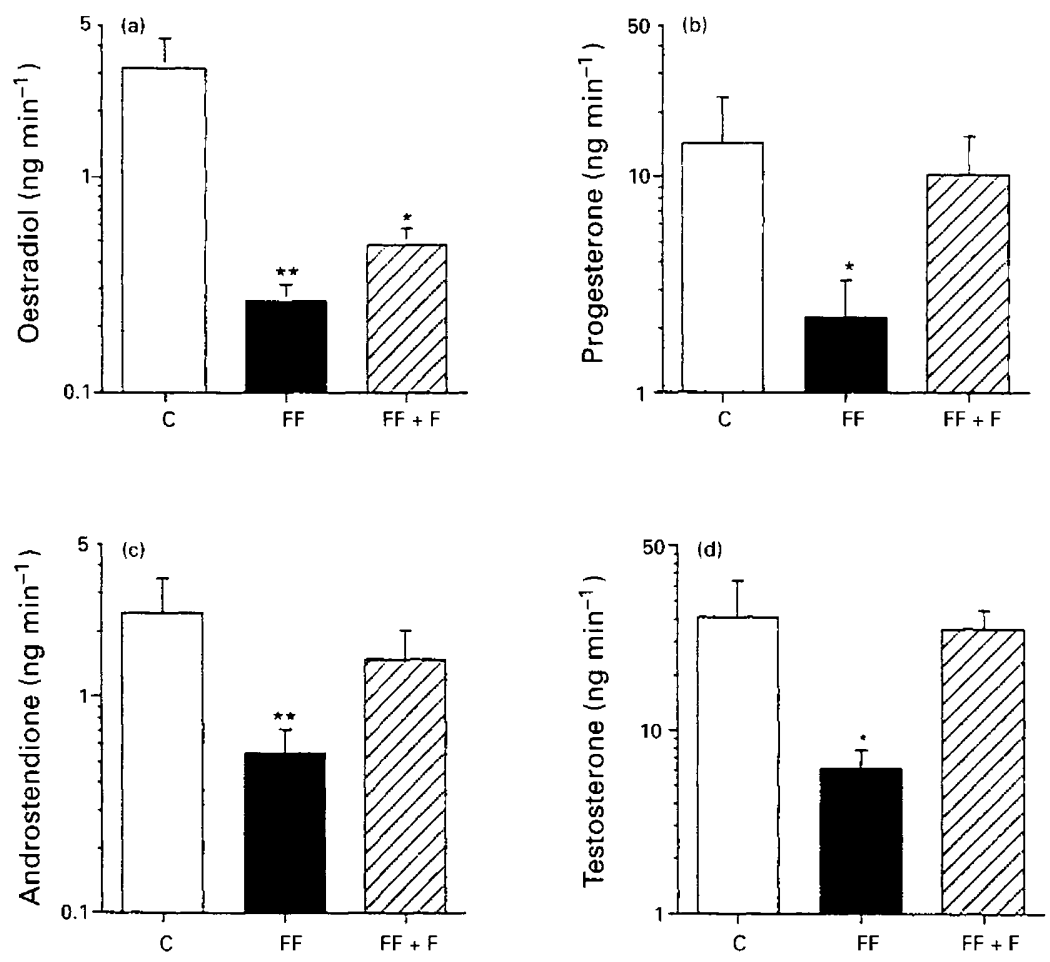

Fig. 3. Ovarian secretion rates of (a) oestradiol, (b) progesterone, (c) androstenedione and (d) testosterone determined before ovariectomy in control ewes $(C ; \square ; n=7)$, ewes treated with follicular fluid (FF; $\square ; n=9)$ and ewes treated with follicular fluid plus FSH (FF $+F ; \forall ; ; n=8)$. Values are mean \pm SEM. ${ }^{*} P<0.05$, ${ }^{*} P<0.01$ for comparison with control.

The follicular fluid-induced decrease in mRNA expression was not associated with morphological evidence of atresia (sloughing or thinning of granulosa layer and pyknotic nuclei), and none of the large follicles in the sheep treated with follicular fluid appeared to be atretic.

\section{Discussion}

The results of the present study confirm previous reports that treatment of ewes with steroid-free ovine follicular fluid during the follicular phase results in an acute decrease in ovarian steroid secretion that is associated with a $36 \%$ decrease in peripheral FSH concentrations (Baird et al., 1990; Campbell et al., 1991a). However, in addition, the present study shows that this decrease in steroid secretion is associated with a specific decrease in $\mathrm{P} 450_{\text {arom }}$ inhibin-activin $\beta_{\mathrm{B}}$ subunit and thecal LH receptor expression. Furthermore, the fact that FSH cotreatment restored circulating FSH concentrations to normal values and reversed some of the effects of follicular fluid (androstenedione, testosterone and progesterone secretion and inhibin $\beta_{B}$ and thecal LH receptor expression) but not others (oestradiol secretion and $\mathrm{P} 450_{\mathrm{arm}}$ expression) indicates that the actions of follicular fluid are mediated via both central effects on pituitary FSH secretion and by direct ovarian effects on granulosa cell aromatase activity.

The possibility that follicular fluid exerts its actions via both direct and indirect mechanisms helps explain the wide range of effects observed after treatment with follicular fluid. In addition to ovarian steroid secretion, treatment with follicular fluid during the follicular phase reduces the number of granulosa cells, oestradiol content, aromatase activity and in vitro gonadotrophin responsiveness in large follicles (Henderson et al., 1986). Furthermore, by using animals with ovarian autotransplants, treatment with ovine follicular fluid has been shown to acutely inhibit ovarian immunoreactive inhibin secretion (Baird et al., 1990; Campbell et al., 1991a). One of the major strengths of the design used in the present study is its ability to differentiate between direct and FSH-dependent actions of follicular fluid and to identify the mechanism of action at a molecular level.

For instance, one of the most puzzling aspects of our previous studies was the ability of follicular fluid to suppress ovarian androgen secretion acutely (Baird et al., 1990; Campbell et al., 1991a), as androgens are produced solely by thecal cells that are under the trophic control of LH. The fact that $\mathrm{P}^{4} 50_{17 \alpha}$ expression was unaffected by follicular fluid, despite a marked decrease in both androstenedione and testosterone secretion, indicates that follicular fluid is not acting through modulation of the activity of this enzyme. Rather, the fact that thecal LH receptor expression was decreased by follicular fluid, allied with the knowledge that ovarian androgen secretion is acutely responsive to $\mathrm{LH}$ (Baird et al., 1981), indicates that follicular fluid affects androgen secretion through modulation of LH receptor expression, a hypothesis that is in agreement with the 


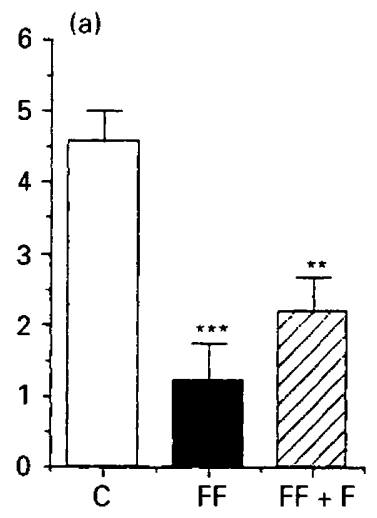

(c)

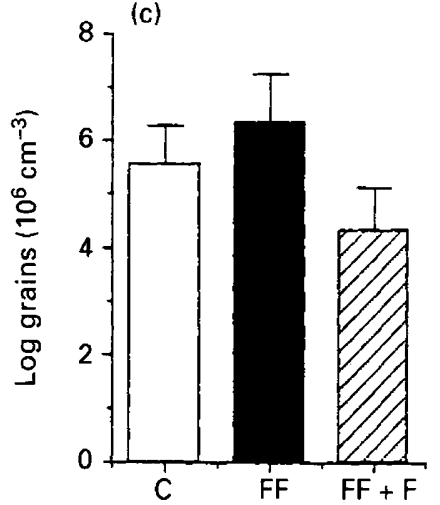

(e)

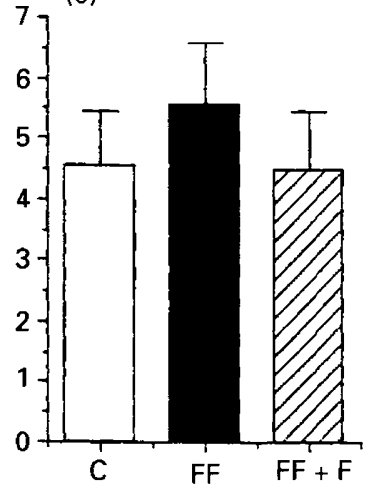

(b)

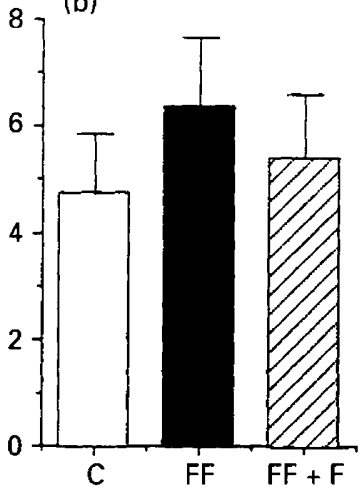

(d)
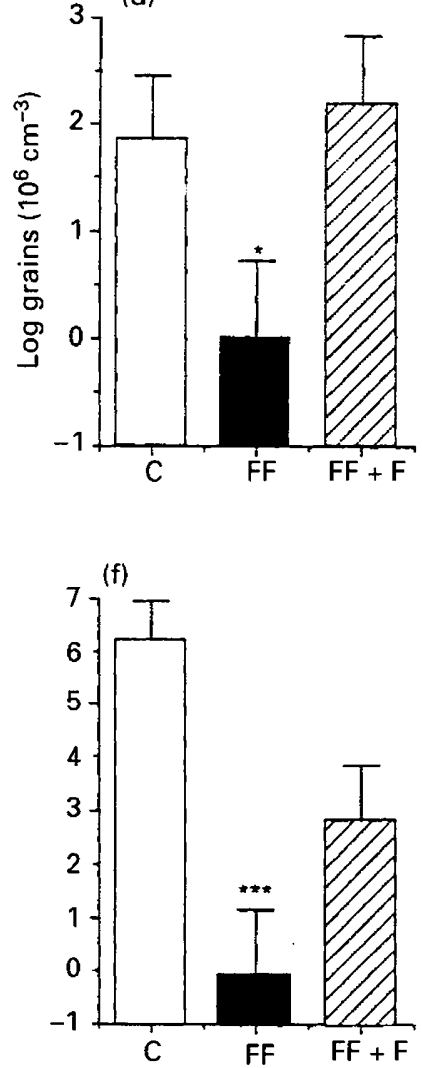

Fig. 4. Expression of RNA for (a) P450 aromatase (b) inhibin $\alpha$ subunit, (c) inhibin $\beta_{A}$ subunit, (d) inhibin $\beta_{B}$ subunit, (e) P450 17 $\alpha$-hydroxylase and (f) thecal $\mathrm{LH}$ receptor in the granulosa $(\mathrm{a}-\mathrm{d})$ and theca $(\mathrm{e}-\mathrm{f})$ cell layers of large (>4 mm in diameter) ovarian follicles in control ewes $(C ; \square ; n=7$ ), ewes treated with follicular fluid (FF; $\square ; n=5$ ) and ewes treated with follicular fluid plus FSH $(\mathrm{FF}+\mathrm{F} ; \mathrm{Q} ; n=6)$. Values are mean $\pm \mathrm{SEM} .{ }^{*} P<0.05,{ }^{* * P}<0.01$, ${ }_{* * *} P<0.001$ for comparison with control.

observation that FSH co-treatment leads to a reversal of the effects of follicular fluid on both LH receptor expression and ovarian androgen secretion. Similarly, as follicular progesterone secretion is also under the acute trophic control of LH (Baird et al., 1976) it is likely that follicular fluid inhibits progesterone secretion via the same mechanism. However, the fact that FSH treatment is able to affect LH receptor expression on thecal cells, which are devoid of FSH receptors (Carson et al., 1979; McNatty et al., 1986, Eckery et $a l ., 1996)$ supports the notion that granulosa cell-derived paracrine factors can modulate thecal function (Smyth et al., 1993).

Owing to the interference of the inhibin contained within the follicular fluid that was injected, in this particular study 
(a)
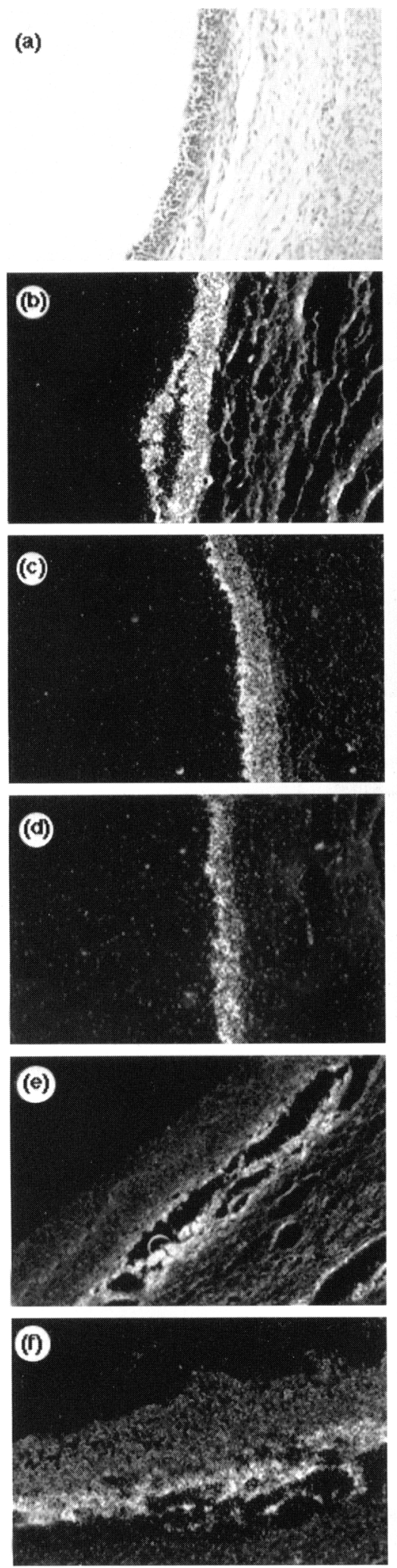

(g)

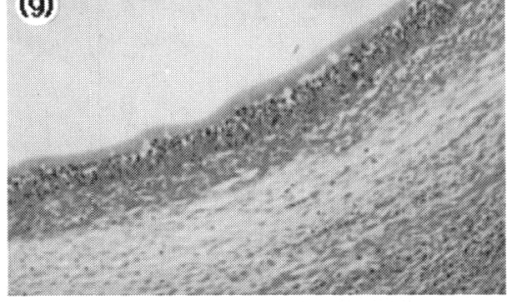

(h)

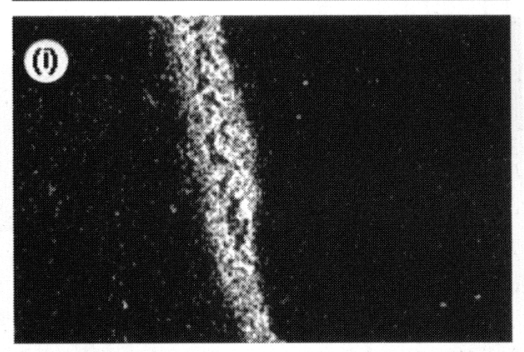

(i)
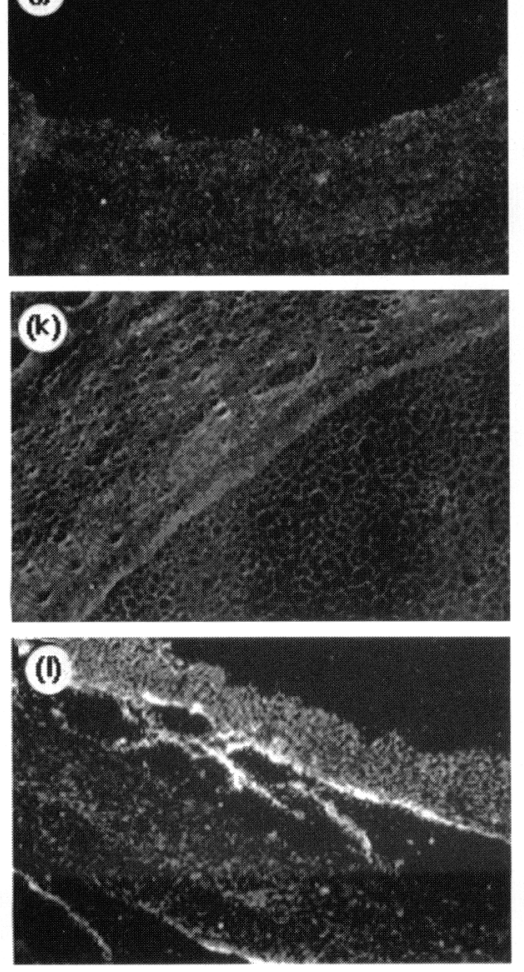

(m)
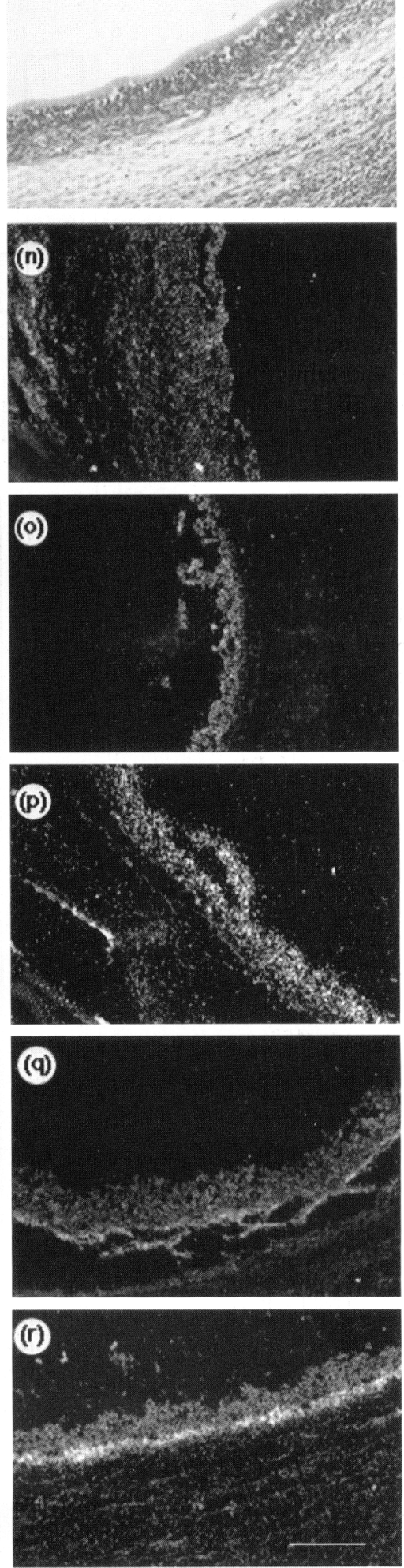

Fig. 5. In sifu hubridization oDNA probes of sheep follicles in follicular phase: (a f) control; (g-l), after treatment with owine

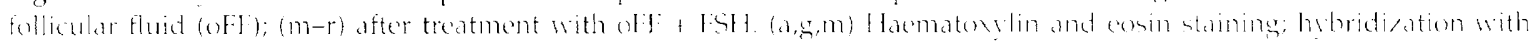

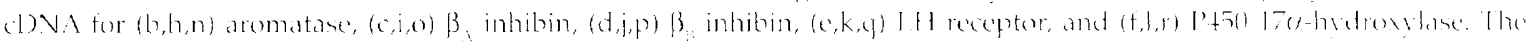
distertion of amotons is an artefact of precesong. Scale har represents $0.5 \mathrm{~mm}$. 
there has been no attempt to determine the effect of follicular fluid treatment on ovarian inhibin secretion. However, by taking repeated samples of ovarian venous blood from ewes with an ovarian autotransplant, it has been shown that ovarian secretion of total immunoreactive inhibin is acutely suppressed by follicular fluid (Baird et al., 1990; Campbell $e t$ al., 1991a). As treatment with follicular fluid in the present experiment had no effect on inhibin $\alpha$ or $\beta_{A^{\prime}}$ but depressed $\beta_{B}$ expression, it appears likely that this decrease in immunoreactive inhibin is due to a decrease in inhibin $B$ rather than inhibin A secretion. This is a surprising finding, since inhibin A appears to be the product of large antral follicles in a number of species, including rats (Woodruff $e t$ al., 1996) and humans (Groome et al., 1996; Souza et al., 1997c), and inhibin A and aromatase are often co-expressed in sheep (B. K. Campbell and D. T. Baird, unpublished). However, little is known about the pattern of secretion of inhibin B in sheep and determination of its relative importance must await the development of specific assays. Nevertheless, the ability of FSH to reverse the depressive effect of follicular fluid on follicular $\beta_{\mathrm{B}}$ expression is consistent with a number of studies in vivo (Tsonis et al., 1986; McNeilly et al., 1989; Campbell et al., 1998) and in vitro (Campbell et al., 1996b) showing that inhibin secretion in sheep is FSH responsive.

The ability of a follicle to secrete oestradiol is one of the key determinants of follicular health (Baird and McNeilly, 1981) and the level of $P 450_{\text {arom }}$ expression is a key marker of granulosa cell differentiation. Oestradiol production by granulosa cells, both in vivo (McNatty et al., 1985; Campbell et al., 1998) and in vitro (Campbell et al., 1996a), is stimulated by FSH, whereas withdrawal of FSH support in vivo, in the absence of LH, leads to an acute decrease in oestradiol secretion and atresia of dominant follicles (Campbell et al., 1999). In the present experiment, the inability of FSH to reverse the depressive effects of follicular fluid on both oestradiol secretion and $\mathrm{P} 450_{\text {arom }}$ expression indicate that follicular fluid contains a factor, or factors, that act directly on granulosa cells to inhibit aromatase (Campbell et al., 1991a, 1996a). The factors mediating this effect, and their mechanism of action are still unknown but potential candidates include follicle regulatory protein (diZerega et al., 1982, Ono et al., 1986), epidermal growth factor (Murray et al., 1992), transforming growth factor $\alpha$ (Campbell et al., 1994), insulin-like growth factor-binding protein (Shimasaki et al., 1990), inhibin (Campbell et al., 1996a) and granulosa cell inhibitory factor (Hynes et al., 1996). Whether these factors play a role in the selection of the dominant follicle requires further experimentation.

While the results of the present experiment show clearly that FSH was not able to reverse fully the effects of follicular fluid, previous studies from our laboratory have shown that larger doses of FSH can prevent the follicular fluid-induced delay in the onset of oestrus in normal ewes (McNeilly 1985), and that follicular fluid is unable to prevent FSH stimulating follicle development in GnRH-agonist-suppressed ewes (McNeilly et al, 1991). Thus, since the action of the inhibitor can be overcome by high doses of FSH, these findings indicate that the inhibitor ultimately modulates an FSHdependent process. In the present and in previous studies (Henderson et al., 1986), treatment with follicular fluid had no effect on the number or size distribution of follicles at 24-48 h after cloprostenol injection. However, using a treatment regimen similar to that of the present study, Campbell et al. (1991a) reported that the number of large follicles (as determined by daily ultrasound scanning) decreased markedly by $72 \mathrm{~h}$ after cloprostenol injection in ewes treated with follicular fluid. Together, these results indicate that treatment with follicular fluid eventually induces atresia in the preovulatory follicle, that functional changes are detectable within $24 \mathrm{~h}$ of induction of luteal regression, and that actual physical regression of the follicle is evident by $72 \mathrm{~h}$ after cloprostenol injection.

In summary, the decrease in FSH concentrations after treatment with steroid-free ovine follicular fluid during the follicular phase results in an acute decrease in ovarian steroid secretion, which is associated with a specific depression in $P 450_{\text {arom }}$ inhibin-activin $\beta_{\mathrm{B}}$ subunit and thecal $\mathrm{LH}$ receptor expression. FSH co-treatment was able to restore circulating FSH concentrations to normal values and reverse some of the effects of follicular fluid (androstenedione, testosterone and progesterone secretion and inhibin $\beta_{\mathrm{B}}$ and thecal LH receptor expression) but not others (oestradiol secretion and $\mathrm{P}^{4} \mathrm{O}_{\text {arom }}$ expression). It is concluded that the actions of follicular fluid are mediated via both central effects on pituitary FSH secretion and by direct ovarian effects on granulosa cell aromatase activity. Further investigations into the identity of this inhibitory activity and its mechanism of action may shed light on the endocrine and paracrine conditions required for the prevention of atresia of follicles at this advanced stage of development.

The authors wish to thank $N$. Anderson and the staff at the Marshall Building for assistance with animals and surgery; $N$. Evans, M. Millar and W. Struthers for technical assistance; The National Hormone and Pituitary Program (University of Maryland School of Medicine, Baltimore, MD) for some of the hormones used for radioimmunoassay; R. G. Forage (Biotechnology Australia Pty Ltd, Sydney, Australia) for the inhibin cDNAs; H. A. Garverick of the University of Missouri and D. G. Armstrong of the Roslin Institute for the LHR and P45017 $\alpha$ cDNAs. This work was supported by MRC programme grant number 892953.

\section{References}

Adams GP, Matteri RL, Kastelic JP, Ko JCH and Ginther OJ (1992) Association between surges of follicle stimulating hormone and the emergence of follicular waves in heifers Journal of Reproduction and Fertility 94 177-188

Baird DT (1983) Factors regulating the growth of the preovulatory follicle in the sheep and human Journal of Reproduction and Fertility 69 343-352

Baird DT and McNeilly AS (1981) Gonadotrophic control of follicular development and function during the oestrous cycle of the ewe Journal of Reproduction and Fertility Supplement 30 119-133

Baird DT, Swanston I and Scaramuzzi RJ (1976) Pulsatile release of LH and secretion of ovarian steroids in sheep during the luteal phase of the estrous cycle Endocrinology 98 1490-1496

Baird DT, Swanston IA and McNeilly AS (1981) Relationship between LH, FSH and prolactin concentrations and the secretion of androgens and estrogens by the preovulatory follicle in the ewe Biology of Reproduction 24 1013-1025

Baird DT, Campbell BK and McNeilly AS (1990) Ovine follicular fluid suppresses the ovarian secretion of androgens, oestradiol and inhibin Journal of Endocrinology 127 23-32

Baxter GB, O'Shea T, Campbell BK and Webb R (1995) Effect of bovine follicular fluid (bFF) fractions, which delay oestrus in sheep and cattle, on 
proliferation and steroid production by cultured granulosa cells Journal of Reproduction and Fertility Abstract Series 15 Abstract 189

Campbell BK, Mann GE, McNeilly AS and Baird DT (1990) The pattern of ovarian inhibin, estradiol and androstenedione secretion during the estrous cycle of the ewe Endocrinology 127 227-235

Campbell BK, Picton HM, Mann GE, McNeilly AS and Baird DT (1991a) Effect of steroid- and inhibin-free ovine follicular fluid on ovarian follicles and ovarian hormone secretion Journal of Reproduction and Fertility 93 81-96

Campbell BK, McNeilly AS, Mann GE and Baird DT (1991b) The effect of stage of estrous cycle and follicular maturation on ovarian inhibin production in sheep Biology of Reproduction $44483-490$

Campbell BK, Gordon BM and Scaramuzzi RJ (1994) The effect of ovarian arterial infusion of transforming growth factor alpha on ovarian follicle populations and ovarian hormone secretion in ewes with an autotransplanted ovary foumal of Endocrinology 143 31-24

Campbell BK, Tsonis CG, Gordon BM and Scaramuzzi RJ (1996a) Ovarian arterial infusion of recombinant human inhibin and bovine follicular fluid inhibits ovarian oestradiol secretion Journal of Endocrinology 149 531-540

Campbell BK, Scaramuzzi RJ and Webb R (1996b) Induction and maintenance of oestradiol and immunoreactive inhibin production with FSH by ovine granulosa cells cultured in serum-free media Journal of Reproduction and Fertility $1067-16$

Campbell BK, Dobson $\mathbf{H}$ and Scaramuzzi RJ (1998) Ovarian function in ewes made hypogonadal with GnRH-antagonist and stimulated with $\mathrm{FSH}$ in the presence or absence of low amplitude LH pulses Journal of Endocrinology 156 213-222

Campbell BK, Dobson $\mathbf{H}$ and Scaramuzzi RJ (1999) Examination of the relative roles of FSH and $\mathrm{LH}$ in the mechanism of ovulatory follicle selection in sheep Iournal of Reproduction and Fertility 117 355-367

Carson RS, Findlay JK, Burger HG and Trounson AO (1979) Gonadotrophin receptors of the ovine ovarian follicle during follicular growth and atresia Biology of Reproduction $2175-87$

Collett RA, Land RB and Baird DT (1973) The pattern of progesterone secretion by the autotransplanted ovary of the ewe in response to ovine luteinizing hormone Journal of Endocrinology 56 403-411

DiZerega GS, Goebelsmann U and Nakamura RM (1982) Identification of protein(s) secreted by the preovulatory ovary which suppresses the follicle response to gonadotropins Joumal of Clinical Endocrinology and Metabolism $\mathbf{5 4}$ 1091-1096

Eckery DC, Moeller CL, Nett TM and Sawyer HR (1997) Localization and quantification of binding sites for follicle-stimulating hormone, luteinizing hormone, growth hormone and insulin-like growth factor 1 in sheep ovarian follicles Biology of Reproduction 57 507-513

Engelhardt H, Smith KB, McNeilly AS and Baird DT (1993) Expression of messenger ribonucleic acid for inhibin subunits and ovarian secretion of inhibin and estradiol at various stages of the sheep estrous cycle Biology of Reproduction 49 281-294

Ginther OJ, Kot K and Wiltbank MC (1995) Associations between emergence of follicular waves and fluctuations in FSH concentrations during the estrous cycle in ewes Theriogenology 43 689-703

Gong JG, Bramley TA and Webb R (1993) The effect of recombinant bovine somatotrophin on ovarian follicular growth and development in heifers Journal of Reproduction and Fertility 97 247-254

Gong JG, Campbell BK and Webb R (1996) Effects of infusion with FSH, with or without $\mathrm{LH}$, on ovarian follicle growth and development in GnRH agonisttreated heifers Journal of Reproduction and Fertility Abstract Series 18 Abstract 9

Groome N, Illingworth P, O'Brien M, Pai R, Mather J and McNeilly AS (1996) Measurement of dimeric inhibin $B$ throughout the human menstrual cycle Journal of Clinical Endocrinology and Metabolism 81 1400-1405

Harkness LM and Baird DT (1997) Morphological and molecular characteristics of living human fetuses between Carnegie stages 7 and 23: localization of inhibin $\mathrm{mRNA} \alpha$ and $\beta$ a subunits by in situ hybridization Human Reproduction Update 3 9-78

Henderson KM, Prisk MD, Hudson N, Ball K, McNatty KP, Lun S, Heath D, Kieboom LE and McDiarmid J (1986) Use of bovine follicular fluid to increase ovulation rate or prevent ovulation in sheep Journal of Reproduction and Fertility 76 623-635

Henderson KM, Savage LC, Ellen RL, Ball K and McNatty KP (1988) Consequences of increasing or decreasing plasma FSH concentrations during the follicular phase in Romney ewes Journal of Reproduction and Fertility 84 187-196

Hynes AC, Kane MT and Sreenan JM (1996) Partial purification from bovine follicular fluid of a low molecular mass with inhibitory effects on the proliferation of bovine granulosa cells in vitro and on rat follicular development in vivo. Journal of Reproduction and Fertility 108 185-191

Law AS, Baxter G, Logue DN, O'Shea T and Webb R (1992) Evidence for the action of bovine follicular fluid factors other than inhibin in suppressing follicular development and delaying oestrus in heifers Journal of Reproduction and Fertility $96603-616$

Leversha LJ, Robertson DM, deVos FL, Morgan FJ, Hearn MTW, Wettenhall REH, Findlay JK, Burger HG and de Kretser DM (1987) Isolation of inhibin from ovine follicular fluid Journal of Endocrinology 113 213-221

McNatty KP, Hudson N, Gibb M, Ball K, Henderson KM, Heath DA, Lun S and Kieboom LE (1985) FSH influences follicle viability, oestradiol biosynthesis and ovulation rate in Romney ewes Journal of Reproduction and Fertility 75 121-131

McNatty KP, O'Keefe LE, Henderson KM, Heath DA and Lun S (1986) ${ }^{125} \mathrm{I}-$ labelled hCG binding characteristics in theca interna and other tissues from Romney ewes and from Booroola $\times$ Romney ewes with and without a major gene influencing their ovulation rate Journal of Reproduction and Fertility 77 $477-488$

McNeilly AS (1984) Changes in FSH and the pulsatile secretion of LH during the delay in oestrus induced by treatment of ewes with bovine follicular fluid Journal of Reproduction and Fertility 72 165-172

McNeilly AS (1985) Effect of changes in FSH induced by bovine follicular fluid and FSH infusion in the preovulatory phase on subsequent ovulation rate and corpus luteum function in the ewe Journal of Reproduction and Fertility 74 661-668

McNeilly AS and Fraser HM (1987) Effect of gonadotrophin-releasing hormone agonist-induced suppression of LH and FSH on follicular growth and corpus luteum function in the ewe Journal of Endocrinology 115 273-282

McNeilly AS, Swanston IA, Crow W, Tsonis CG and Baird DT (1989) Changes in the plasma concentrations of inhibin throughout the normal sheep oestrous cycle and after the infusion of FSH journal of Endocrinology 120 295-305

McNeilly AS, Crow W and Campbell BK (1991) Effect of follicular fluid and inhibin immunoneutralisation on FSH-induced preovulatory follicle growth in the ewe Joumal of Endocrinology 131 401-409

Mann GE, Campbell BK, McNeilly AS and Baird DT (1992) The role of inhibin and oestradiol in the control of FSH secretion in the sheep Journal of Endocrinology 3 381-391

Murray JF, Downing JA, Evans G, Findlay JK and Scaramuzzi RJ (1992) Epidermal growth factor acts directly on the ovary in vivo to inhibit oestradiol-17 $\beta$ and inhibin secretion and enhance progesterone secretion Journal of Endocrinology 137 253-264

Ono T, Campeau JD, Holmber EA, Nakamura RM, Ujita EL, Tonetta SA, DeVinna R, Uagalde $M$ and diZerega GS (1986) Biochemical and physiologic characterization of follicle regulatory protein: a paracrine regulator of folliculogenesis American loumal of Obstetrics and Gynecology 154 709-716

Picton HM, Tsonis CG and McNeilly AS (1990) FSH causes a time-dependent stimulation of preovulatory follicle growth in the absence of pulsatile LH secretion in ewes chronically treated with gonadotrophin-releasing hormone agonist Journal of Endocrinology 126 297-307

Scaramuzzi RJ, Adams NR, Baird DT, Campbell BK, Downing JA, Findlay JK, Henderson KM, Martin GB, McNatty KP, McNeilly AS and Tsonis CG (1993) A model for follicle selection and the determination of ovulation rate in the ewe Reproduction Ferility and Development 5 459-478

Shimasaki S, Shimonaka M, Ui M, Inouye S, Shibata F and Ling N (1990) Structural characterization of a follicle-stimulating hormone action inhibitor in porcine follicular fluid. Its identification as the insulin-like growth factor-binding protein Journal of Biological Chemistry 265 2198-2205

Smyth CD, Miro F, Whitelaw PF, Howles CM and Hillier SG (1993) Ovarian thecal/interstitial androgen synthesis is enhanced by a follicle-stimulating hormone-stimulated paracrine mechanism Endocrinology 133 1532-1538

Souza CJH, Campbell BK and Baird DT (1997a) Follicular development and concentrations of ovarian steroids and inhibin $\mathrm{A}$ in jugular venous plasma during the luteal phase of the oestrous cycle Journal of Endocrinology 156 563-572

Souza CJH, Campbell BK and Baird DT (1997b) Follicular dynamics and ovarian steroid secretion in sheep during the follicular and early luteal phases of the estrous cycle Biology of Reproduction 56 483-488

Souza CJH, Campbell BK, Baird DT and Webb R (1997c) Secretion of inhibin $A$ and follicular dynamics throughout the oestrous cycle in sheep with and without the Booroola gene ( $F e c B)$ Endocrinology 138 5333-5340

Tsonis CG, McNeilly AS and Baird DT (1986) Measurement of exogenous and endogenous inhibin in sheep serum using a new and extremely sensitive bioassay for inhibin based on inhibition of ovine pituitary FSH secretion in vitro. Journal of Endocrinology 117 283-291 
Turnbull KE, Braden AWH and Mattner PE (1977)The pattern of follicular growth and atresia in the ovine ovary Australian Journal of Biological Sciences 30 229-241

Wallace JM and McNeilly AS (1986) Changes in FSH and the pulsatile secretion of LH during treatment of ewes with bovine follicular fluid throughout the luteal phase of the estrous cycle Journal of Endocrinology 73 505-515

Woodruff TK, Besecke LM, Groome N, Draper LB, Schwartz NB and Weiss J (1996) Inhibin A and inhibin B are inversely correlated to folliclestimulating hormone, yet are discordant during the follicular phase of the rat estrous cycle, and inhibin $A$ is expressed in a sexually dimorphic manner Endocrinology 137 5463-5467

Xu ZZ, Garvenik HA, Smith GW, Smith MF, Hamilton RS and Youngquist RS (1995a) Expression of follicle-stimulating hormone and luteinizing hormone receptor ribonucleic acids in bovine follicles during the first follicular wave Biology of Reproduction 53 951-957

Xu ZZ, Garvenik HA, Smith GW, Smith FS, Hamilton SA and Youngquist RS (1995b) Expression of messenger RNA encoding cytochrome $P_{+501}$ side-chain cleavage, cytochrome $P_{4 \pi \overline{1}} 17 \alpha$-messenger RNA and cytochrome $P_{+5 \times 1}$ aromatase in bovine follicles during the first follicular waves Endocrinology 136 981-989 